\title{
Magnetic anomalies of offshore Krishna-Godavari basin, eastern continental margin of India
}

\author{
K V Swamy ${ }^{1}$, I V Radhakrishna Murthy ${ }^{2}$, K S Krishna ${ }^{3, *}$, K S R Murthy ${ }^{4}$, \\ A S SUBRAHMANYAM ${ }^{4}$ and M M Malleswara RAO ${ }^{4}$ \\ ${ }^{1}$ Department of Geo-informatics, Adikavi Nannaya University, Rajahmundry 533 105, India. \\ ${ }^{2}$ Department of Geophysics, Andhra University, Visakhapatnam 530 003, India. \\ ${ }^{3}$ National Institute of Oceanography, Council of Scientific and Industrial Research, \\ Dona Paula, Goa 403 004, India. \\ ${ }^{4}$ Regional Centre, National Institute of Oceanography, Council of Scientific and \\ Industrial Research, Visakhapantam 530 017, India. \\ *e-mail: krishna@nio.org
}

The marine magnetic data acquired from offshore Krishna-Godavari $(\mathrm{K}-\mathrm{G})$ basin, eastern continental margin of India (ECMI), brought out a prominent NE-SW trending feature, which could be explained by a buried structural high formed by volcanic activity. The magnetic anomaly feature is also associated with a distinct negative gravity anomaly similar to the one associated with $85^{\circ} \mathrm{E}$ Ridge. The gravity low could be attributed to a flexure at the Moho boundary, which could in turn be filled with the volcanic material. Inversion of the magnetic and gravity anomalies was also carried out to establish the similarity of anomalies of the two geological features (structural high on the margin and the $85^{\circ} \mathrm{E}$ Ridge) and their interpretations. In both cases, the magnetic anomalies were caused dominantly by the magnetization contrast between the volcanic material and the surrounding oceanic crust, whereas the low gravity anomalies are by the flexures of the order of 3-4 km at Moho boundary beneath them. The analysis suggests that both structural high present in offshore Krishna-Godavari basin and the $85^{\circ} \mathrm{E}$ Ridge have been emplaced on relatively older oceanic crust by a common volcanic process, but at discrete times, and that several of the gravity lows in the Bay of Bengal can be attributed to flexures on the Moho, each created due to the load of volcanic material.

\section{Introduction}

The Bengal Fan and the eastern continental margin of India (ECMI) have been the seats of vigorous geophysical exploration for several decades. Studies on ECMI are significant due to the presence of major river basins such as Cauvery, Krishna-Godavari and Mahanadi on it. These river basins were formed due to the break-up of the Peninsular India from the Combined Antarctica and Australia and subsequent down-warping of the eastern part of the Indian shield (Sahni 1982), and hence studies on the continental margins help in understanding the events that occurred during the break-up. Of these, the Krishna-Godavari $(\mathrm{K}-\mathrm{G})$ basin with its high hydrocarbon production potential, extending over $28,000 \mathrm{~km}^{2}$ on land, $24,000 \mathrm{~km}^{2}$ in 'shallow' (by current definition, a depth of up to $400 \mathrm{~m}$ ) waters offshore and $18,000 \mathrm{~km}^{2}$ in deep waters (up to $2000 \mathrm{~m}$ ), was relatively better surveyed (Shastri et al 1973, 1974; Shenai and Rao 1982; Kumar 1983; Venkateswarlu et al 1992a, 1992b; Murthy et al 1995) than the other eastern margin basins.

A significant magnetic anomaly closure was identified on the continental slope off Machilipatnam

Keywords. Magnetic anomalies; Krishna-Godavari basin; eastern continental margin of India; $85^{\circ} \mathrm{E}$ Ridge. 


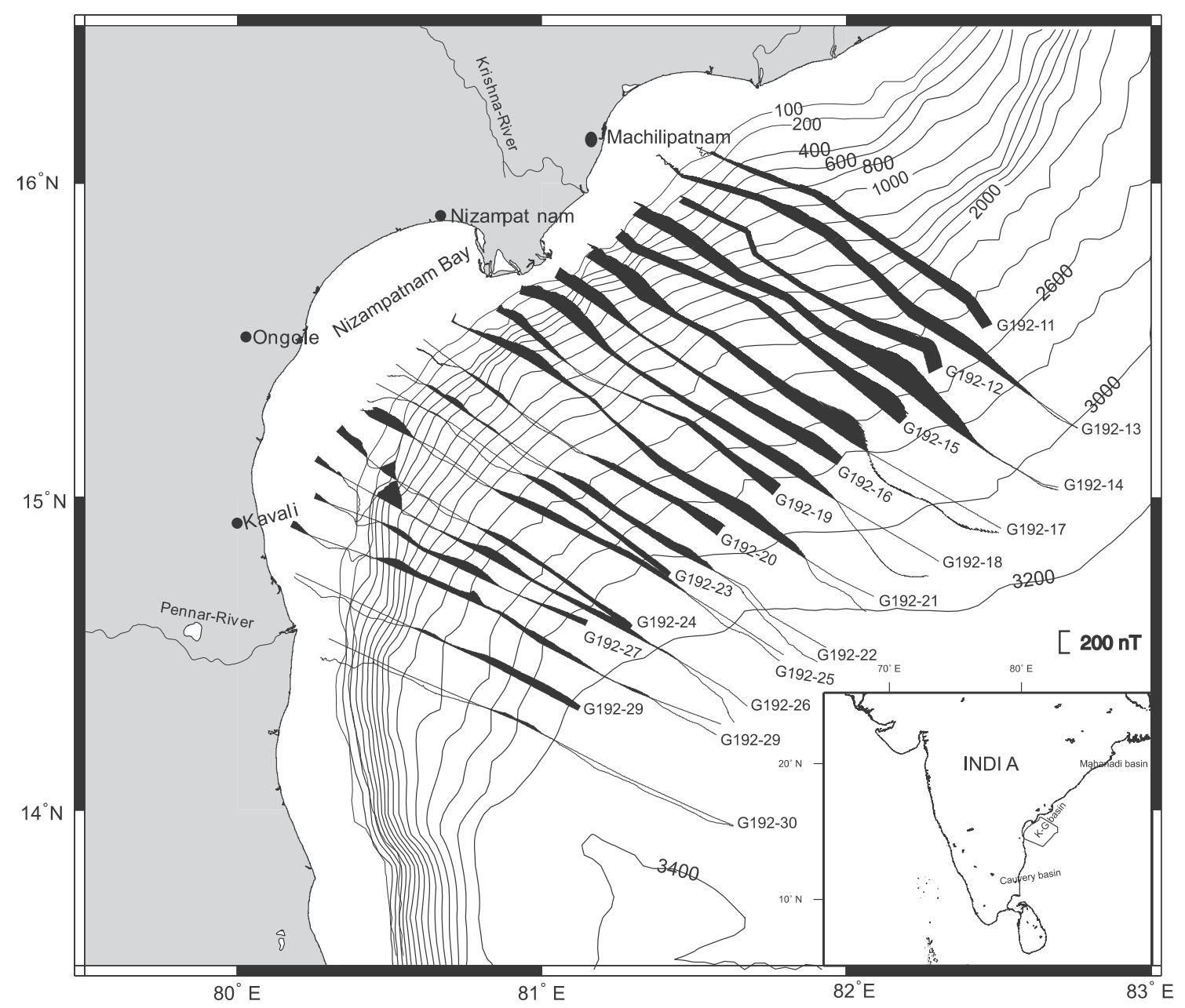

Figure 1. Total field magnetic anomaly profiles overlapped above the etopo5 bathymetry contours of a part of offshore $\mathrm{K}-\mathrm{G}$ basin, India, plotted along the cruise tracks. The darkened portions along the profiles represent the positive anomalies. The bathymetry values are in meters.

(location is shown in figure 1) in offshore $\mathrm{K}-\mathrm{G}$ basin by Venkateswarlu et al (1992b). They attributed it to a submerged volcano without giving any explanation for its origin. Subsequently Murthy et al (1995) from their preliminary reconstruction of the evolutionary stages of the offshore $\mathrm{K}-\mathrm{G}$ basin have also identified the same magnetic anomaly feature from their data. Interestingly, this isolated magnetic anomaly feature coincides with one of the several conspicuous gravity lows present in the Bay of Bengal (Gopala Rao et al 1997; Subrahmanyam et al 2001; Krishna 2003; Krishna et al 2009). The gravity low corresponding to the present magnetic anomaly can be identified with the feature marked as E in figure 2 of Subrahmanyam et al (2001). Subrahmanyam et al (2001) modeled the strong gravity low associated with the submerged $85^{\circ} \mathrm{E}$ Ridge and convincingly attributed it to a depression-like structure in the Moho, created by the volcanic load of the ridge which has as much density as that of the oceanic crust. The proposition of Subrahmanyam et al (2001) differed from the other interpretations which attributed the strong gravity low of the $85^{\circ} \mathrm{E}$ Ridge to several anomaly sources, viz., thickening of the crust beneath the ridge on account of the isostatic compensation (Liu et al 1982; Gopala Rao et al 1997; Subrahmanyam et al 1999), an up-warped model of the ridge with a low-density crust and a shallow root (Ramana et al 1997) and combined sources of meta-sediments having high densities against the volcanic material, and flexure at Moho boundary due to volcanic load of the ridge (Krishna 2003). Subrahmanyam et al (2001) have also opined that each gravity low in the Bay of Bengal should be associated with a structural high like feature as in the case of $85^{\circ} \mathrm{E}$ Ridge, and need to be explained by a corresponding flexure in the mantle.

In this paper, a prominent NE-SW trending isolated magnetic anomaly feature and the associated gravity low in the offshore $\mathrm{K}-\mathrm{G}$ basin, ECMI, were inverted for determining the source and discussed its probable evolution. The anomalies of the present feature are found to be similar to those of 


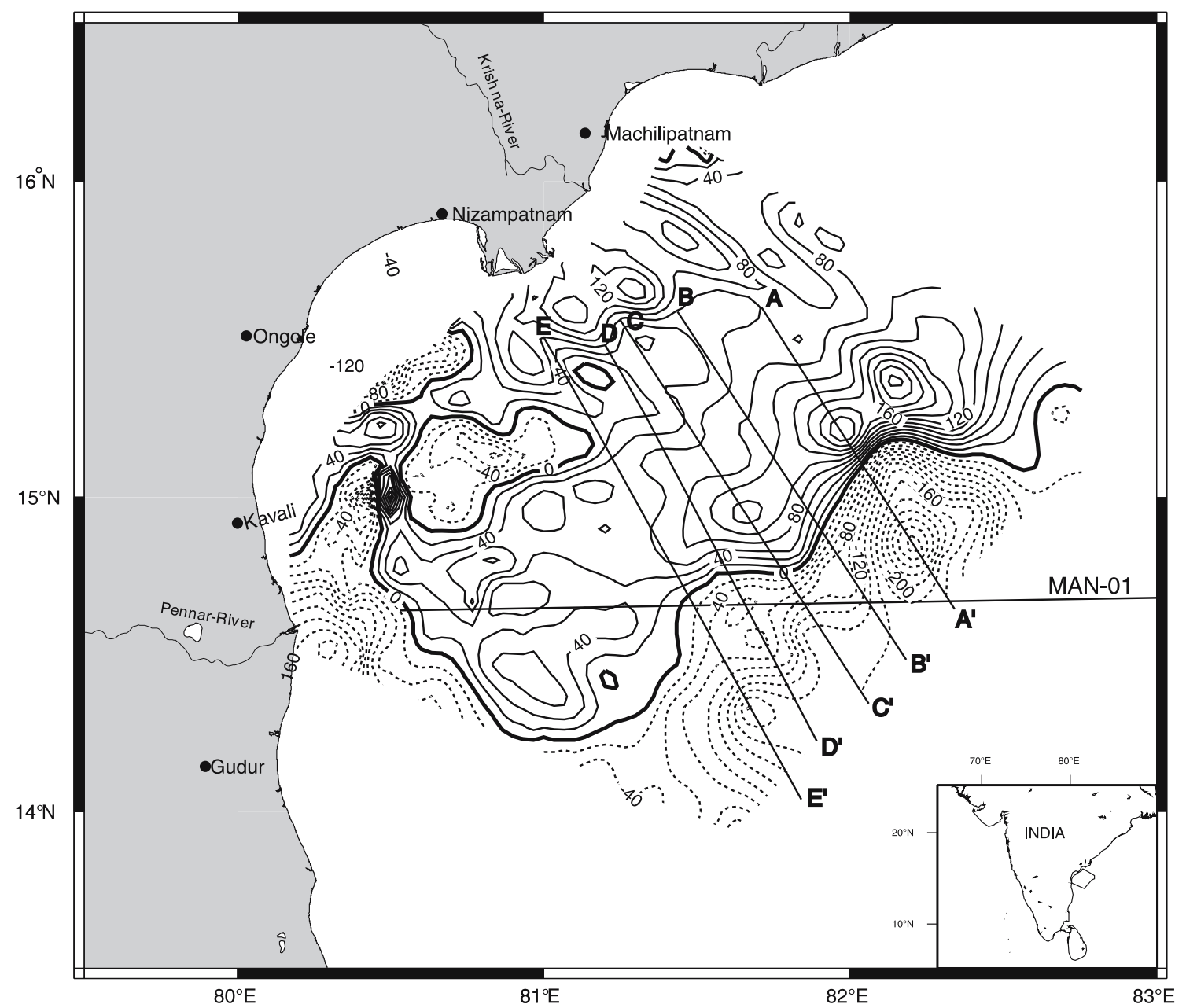

Figure 2. Magnetic anomaly map of the off-shore Krishna-Godavari Basin contoured at an interval of $20 \mathrm{nT}$. Solid contours indicate positive anomalies and dashed contours the negative anomalies. The lines $\mathrm{A}-\mathrm{A}^{\prime}, \mathrm{B}-\mathrm{B}^{\prime}, \mathrm{C}-\mathrm{C}^{\prime}, \mathrm{D}-\mathrm{D}^{\prime}$ and $\mathrm{E}-\mathrm{E}^{\prime}$ indicate the profiles along which the anomalies were inverted for causative structures. The E-W line indicates the position of the MAN-01 cruise track (see figure 3) in the study area. The ship tracks were also indicated in grayish scale.

the $85^{\circ} \mathrm{E}$ Ridge and the genesis of both the features is the same.

\section{Geophysical data and magnetic anomaly character}

Bathymetry and total field magnetic data along twenty NW-SE profiles (G192-11 to G192-30), totaling about 3100 line kilometers and covering an area of about $67,200 \mathrm{~km}^{2}$ on ECMI between $80.2^{\circ} \mathrm{E}$ and $82.8^{\circ} \mathrm{E}$ longitudes and $14^{\circ} \mathrm{N}$ and $16.2^{\circ} \mathrm{N}$ latitudes were collected during the 192 cruise of the research vessel $R V$ Gaveshani by the Regional Center of National Institute of Oceanography (NIO), Visakhapatnam (figure 1). Bathymetry and magnetic data were obtained by deploying a Simrad Echo-sounder and Barringer magnetometer. A satellite receiver (MX 1107) was used for positioning during the survey. The magnetic data were corrected for the variation in the regional field
(IGRF). All the profiles are confined to the continental shelf-slope-margin from about $30 \mathrm{~m}$ to $3500 \mathrm{~m}$ water depth. The magnetic anomalies contoured at an interval of $20 \mathrm{nT}$ are also shown in figure 2 .

Published seismic reflection results along $14.64^{\circ} \mathrm{N}$ latitude from ECMI to the $85^{\circ} \mathrm{E}$ Ridge (Gopala Rao et al 1997), which brought out the basement details along with the isolated structural feature in the offshore $\mathrm{K}-\mathrm{G}$ basin and the $85^{\circ} \mathrm{E}$ Ridge and the distribution of overlying sedimentary sequences were used in this work to constrain magnetic and gravity interpretations. The seismic results along with gravity and magnetic anomalies of the profile (MAN-01) are shown in figure 3 .

The profile-plots of magnetic anomaly along the ship-tracks (figure 1) and the anomaly contour map (figure 2) bring out low to medium amplitude magnetic signatures ranging from -290 to $+200 \mathrm{nT}$. The entire area is magnetically disturbed and can be divided into two parts, viz., (a) the 


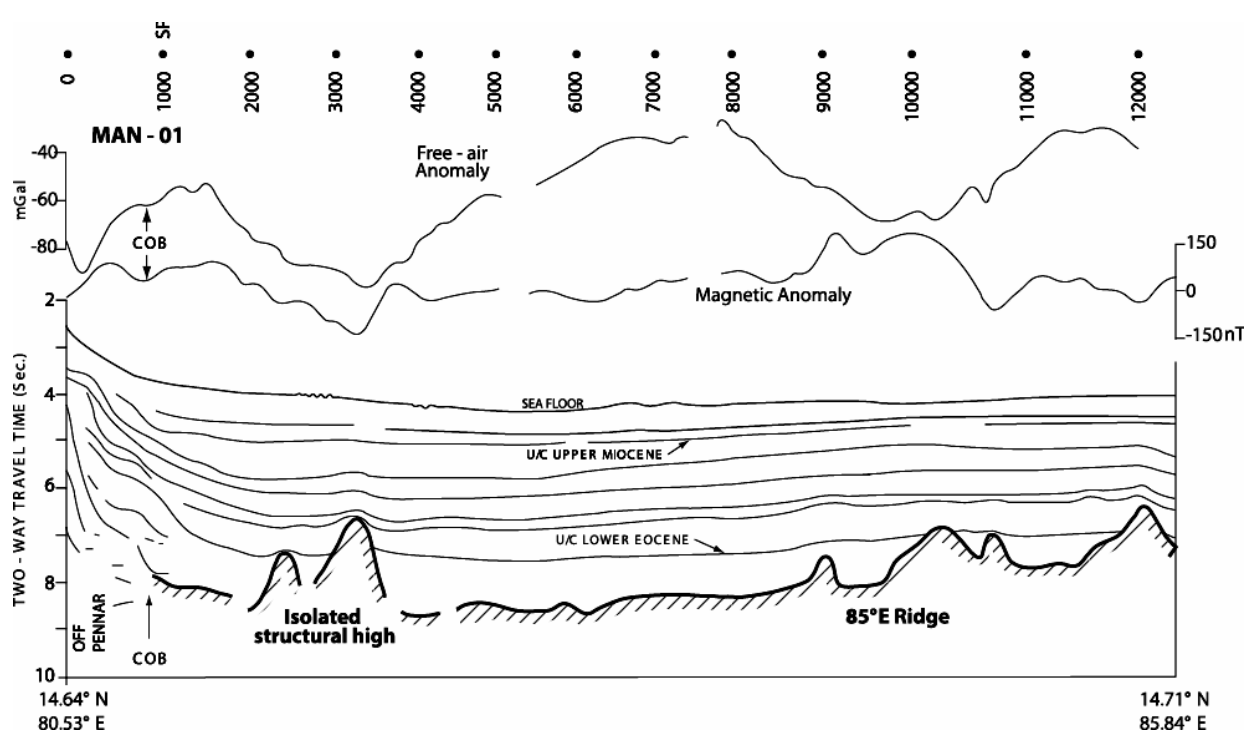

Figure 3. Line section of a part of multi channel section along MAN-01 profile across Bay of Bengal with free-air gravity and total field magnetic anomalies along it. Location of the profile is shown in figure 2 .

western part lying near the coast and (b) the eastern part, between 2400 and $3500 \mathrm{~m}$ isobaths in the abyssal plain. Several high frequency shortwavelength anomalies with different trends are conspicuous in the western part (a) near the coast and they may be related to the continental shelf and slope parts of the study area. The eastern part of the study area, i.e., the abyssal plain shows a conspicuous NE-SW trending anomalous feature extending between $81^{\circ} \mathrm{E}$ and $82.5^{\circ} \mathrm{E}$ longitudes and $14^{\circ} \mathrm{N}$ and $16^{\circ} \mathrm{N}$ latitudes. The positive anomalies are flanked by strong negative anomalies. This is the anomaly feature that was earlier reported by Venkateswarlu et al (1992b) and Murthy et al (1995). This anomaly feature is further investigated in detail in this paper for its genesis, and is compared with that of the $85^{\circ} \mathrm{E}$ Ridge to understand the genetic relations between the two individual geological structures.

\section{Inversion of the magnetic anomalies}

Five principal anomaly profiles were constructed from the magnetic anomaly contour map (figure 2) and were subjected to rigorous quantitative analysis to ascertain the causative source. Initial attempts to explain the anomaly by an intrusion through a dyke model failed because the model results brought out unusual low values of the depth to the dyke which cannot be justified by the seismic results (figure 3 ). These profiles were then inverted for a probable structure at depth using the program TMAG2DIN (Radhakrishna Murthy 1998), which calculates the depths below each observation point to the anomaly-producing interface. The program assumes the undisturbed/mean depth to the interface $(Z)$, intensity of effective magnetization $(J)$ and its dip $(\phi)$. The residual anomalies on each of the profiles were inverted for different combinations $Z, J$ and $\phi$. The values of mean depth were varied between 8 and $15 \mathrm{~km}$ at an interval of $1 \mathrm{~km}$. The intensity of magnetization was similarly varied between $200 \times 10^{-5}$ and $1500 \times 10^{-5} \mathrm{cgs}$ units at an interval of $50 \times 10^{-5} \mathrm{cgs}$ units and different values of dip of effective magnetization were used for the inversion. Each combination of these three parameters gives an independent solution for the given input data. The solution associated with a relatively low value of the objective function, systematically small errors throughout the length of the profile and a comparatively smoother interface without any unreasonable differences in depth between any two successive stations was accepted.

The magnetic anomalies along a typical profile $\mathrm{A}-\mathrm{A}^{\prime}$ (figure $4 \mathrm{~A}$ ) were interpreted for structures at two depths $(11 \mathrm{~km}$ and $14 \mathrm{~km})$ and both the interpretations are presented in figure $4(\mathrm{~A}$ and $\mathrm{B})$. The depth of $11 \mathrm{~km}$ is relevant because, it is at this level the oceanic crust lies in the study area (from the seismic results shown in figure 3). If the interpretation associated with this depth is accepted, the anomaly is deemed to be caused by the structure on the oceanic crust. The equivalent geological model is presented in figure 4(C). The inversion of the profile for this mean depth of $11 \mathrm{~km}$ puts the basement close to $6.0 \mathrm{~km}$, which cannot be explained by the known thickness of $6.5 \mathrm{~km}$ of the water and sediments together over the structural high, as recorded in MAN-01 (Gopala Rao et al 

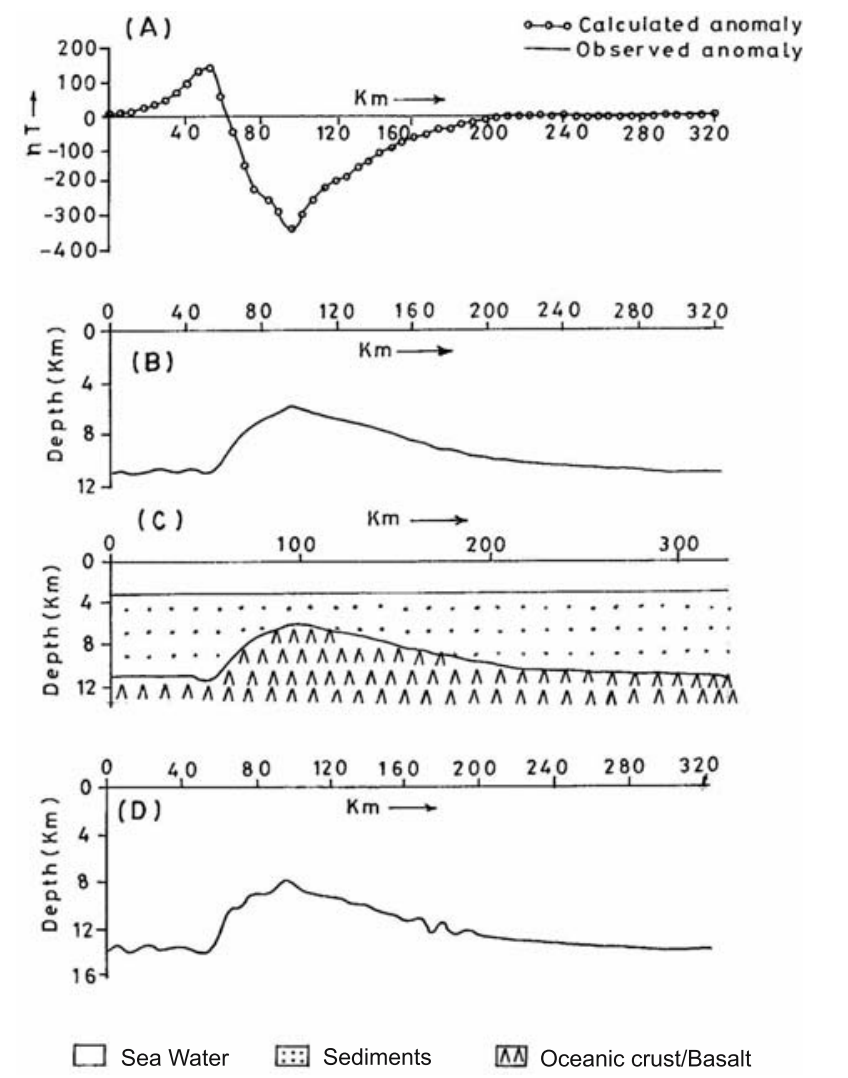

Figure 4. (A) Magnetic anomalies along the profile $\mathrm{A}-\mathrm{A}^{\prime}$ shown in figure 2, and their interpretation for the mean depth at $11 \mathrm{~km}(\mathbf{B})$. The equivalent geological cross-section for (B) is shown in (C). Another possibility of interpretation for the mean depth at $14 \mathrm{~km}(\mathrm{D})$.

1997). Further such a basement structure should produce a strong positive gravity anomaly due to the high density of basalts $(2.9 \mathrm{gm} / \mathrm{cc})$ compared to the sediments $(2.6 \mathrm{gm} / \mathrm{cc})$. However, the gravity anomaly recorded in this region is negative (see figure 3).

On the other hand, the inversion of the profile assuming a mean depth of $14 \mathrm{~km}$ for the interface places the shallowest depth of the source close to $8.0 \mathrm{~km}$ (figure $4 \mathrm{D}$ ), which is below the known thickness of the water column and the sediments above the structural high. The structure has an effective magnetization of $700 \times 10^{-5} \mathrm{cgs}$ units with a dip of $-25^{\circ}$. The chosen depth of $14 \mathrm{~km}$ in the present interpretation is significant for the following reasons. It represents the level where the temperature can be more than $550^{\circ} \mathrm{C}$, i.e., the Curie temperature below which the magnetite mineral loses its magnetic properties and ceases to produce any magnetic anomaly. Also it is approximately $2 \mathrm{~km}$ above the Moho boundary, which is lying at about $16 \mathrm{~km}$ from the sea surface.

Inversion of the magnetic anomalies along the four other profiles, viz., $\mathrm{BB}^{\prime}, \mathrm{CC}^{\prime}, \mathrm{DD}^{\prime}$ and $\mathrm{EE}^{\prime}$ (figure 2) are shown the figure 5. All these profiles consistently bring out a structural high below the sediments whose base is at $14 \mathrm{~km}$ with an effective magnetization of $700 \times 10^{-5} \mathrm{cgs}$ units with a dip of $-25^{\circ}$. In all these cases, the structure did not show depths shallower than $8.0 \mathrm{~km}$.

\section{Interpretation of the gravity low}

The free-air gravity anomalies associated with the region were collected from the MAN-01 profile along $14.64^{\circ} \mathrm{N}$ latitude as shown in figure 3 and projected on to the profile $\mathrm{A}-\mathrm{A}^{\prime}$. This projected gravity low (figure 6A) is inverted through the programme GR2DIN of Radhakrishna Murthy (1998). The low gravity anomaly is assumed to be produced mostly due to the undulations in the Moho at an undisturbed depth of $16 \mathrm{~km}$ with a density contrast of $0.5 \mathrm{gm} / \mathrm{cc}(2.9 \mathrm{gm} / \mathrm{cc}$ for the oceanic crust and $3.4 \mathrm{gm} / \mathrm{cc}$ for the mantle). The assumed undisturbed depth of $16 \mathrm{~km}$ for the Moho is reasonable, because of the established minimum of $3 \mathrm{~km}$ water depth in the $\mathrm{K}-\mathrm{G}$ basin, a sediment thickness of about $8 \mathrm{~km}$ overlying the oceanic crust and the average thickness of $5 \mathrm{~km}$ of the oceanic crust. The inversion shown in figure 6(B) explains the anomaly by a $3-4 \mathrm{~km}$ downward flexure in the Moho boundary. The probable geological cross-section from the combined geophysical interpretation of gravity and magnetic anomalies below the profile $\mathrm{A}-\mathrm{A}^{\prime}$ is shown in figure $6(\mathrm{C})$.

\section{Gravity and magnetic anomalies of the $85^{\circ} \mathbf{E}$ Ridge}

As the geophysical features of the present structure are quite similar to those of the $85^{\circ} \mathrm{E}$ Ridge, its magnetic (figure 7A) and gravity (figure 7C) anomalies were also collected from MAN-01 profile (Gopala Rao et al 1997), and their interpretations are included in figure 7 for comparison. The structure explaining the magnetic anomalies of the $85^{\circ} \mathrm{E}$ Ridge again rested on the $14 \mathrm{~km}$ depth (figure 7B), and its elevated topography coincided extremely well with the seismic results of the $85^{\circ} \mathrm{E}$ Ridge (along profile MAN-01). The gentle rise of the ridge on the east and its sharp fall on the west typically correlate with the known seismic results. The interpretation brings out an effective magnetization of $0.015 \mathrm{cgs}$ units with a dip of $30^{\circ}$. The gravity low of the ridge is again explained by about $3-4 \mathrm{~km}$ downward flexure in the Moho from its undisturbed depth of $16.0 \mathrm{~km}$ (figure 7D). Earlier, Subrahmanyam et al (2001) also have published similar results for the $85^{\circ} \mathrm{E}$ Ridge for other location. The probable geological model lying below the $85^{\circ} \mathrm{E}$ Ridge is shown in figure $7(\mathrm{E})$. 

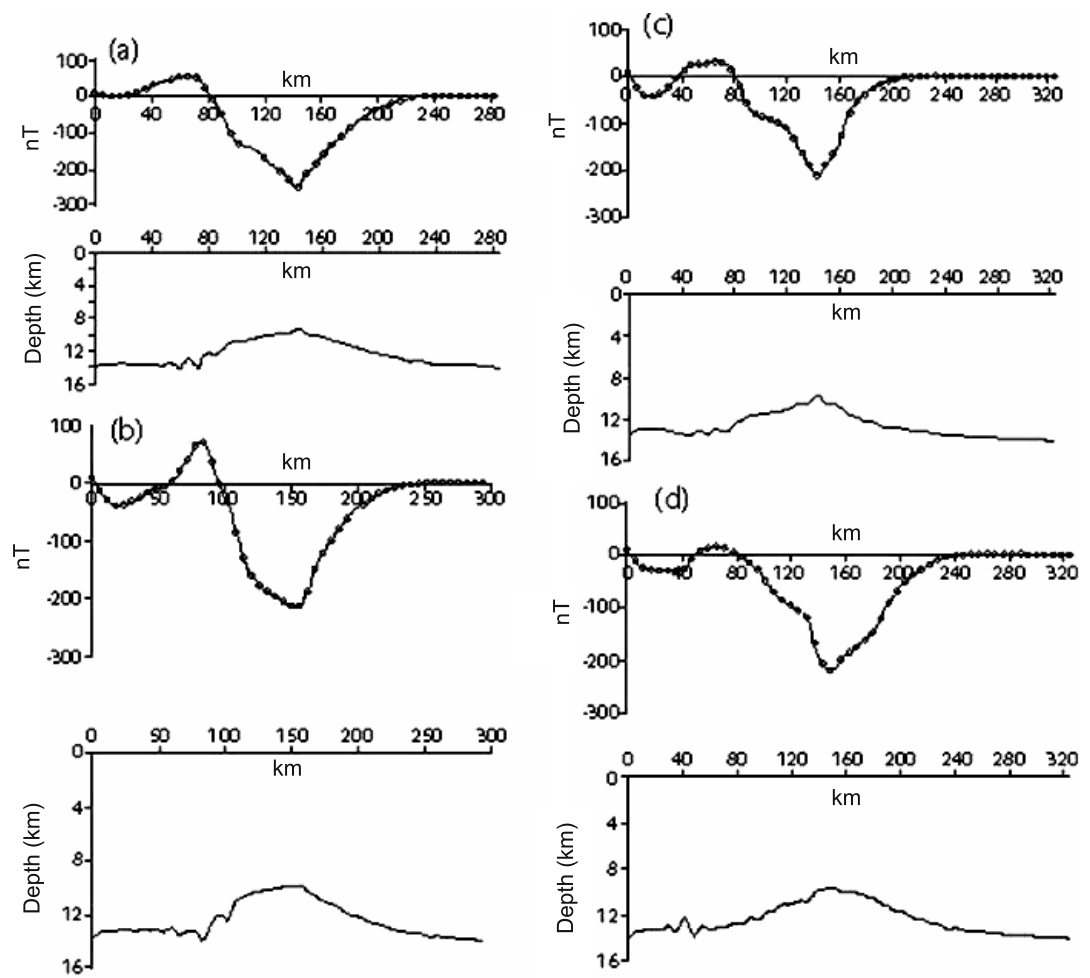

Figure 5. Interpretation of magnetic anomalies along the profiles B-B' (a), C- $\mathrm{C}^{\prime}$ (b), D- $\mathrm{D}^{\prime}$ (c) and E- $\mathrm{E}^{\prime}$ (d) (see figure 2). The circles on the anomaly curves indicate the calculated anomalies.

\section{Discussion}

The inversion of magnetic anomalies in the offshore $\mathrm{K}-\mathrm{G}$ basin indicates the presence of a NE-SW trending buried ridge like feature $(\sim 200 \mathrm{~km}$ in length), which is shown deceptively as a basement high in the seismic reflection data. The observed magnetic anomalies cannot be explained by structures on the oceanic crust; as such an interpretation puts the basement too shallow to be convincingly explained by bathymetry. Such an interpretation is also ruled out by the presence of a negative gravity anomaly. The magnetic feature can only be explained by a feature that is having its base at $14 \mathrm{~km}$. However, ridge like structures on the Moho and their projection into the crust and sediments are simply not possible. Even if possible, such a contingency should produce a strong gravity high, instead of the observed low. Then the logical inference is that the source causing the anomalies is different from that of the crust/mantle material, in which case the source may be a volcanic load emplaced into the already evolved and relatively older oceanic crust. If it is so, all the crust/mantle material below the $14 \mathrm{~km}$ depth and the $3-4 \mathrm{~km}$ depression like structures on the Moho, if any, will not contribute to the magnetic anomalies, due to the high temperatures below $14 \mathrm{~km}$ depth. The anomalies are then caused by the magnetization contrast between the volcanic load above the $14 \mathrm{~km}$ depth and the basaltic layer surrounding the volcanic load on one hand, and the magnetization contrast between the volcanic load and the sediments overlying the basaltic layer on the other, the former, however, contributing a major share. This volcanic load can have the same density as that of the basalt, so that the negative gravity anomaly associated with it is attributed dominantly due to the downward flexures at the Moho boundary. These flexures could have been developed by the emplaced volcanic loads.

This interpretation of gravity and magnetic anomalies is similar to the one on the $85^{\circ} \mathrm{E}$ Ridge. The gravity low of the $85^{\circ} \mathrm{E}$ Ridge was already attributed to a depression like structure in the Moho by Subrahmanyam et al (2001) and to a flexure caused by regional isostatic compensation by Krishna (2003). The magnetic anomalies of the ridge are attributed to the volcanic construct above the Moho level, which can create a depression in the Moho causing the gravity low. Thus the interpretation of gravity and magnetic anomalies in the offshore $\mathrm{K}-\mathrm{G}$ basin compare well with that of the $85^{\circ} \mathrm{E}$ Ridge. Then it can be safely reiterated that several of the gravity lows in the Bay of Bengal, may be associated with flexures in the Moho, which are formed due to and occupied by the volcanic loads that are emplaced into the relatively older oceanic crust and sitting on the oceanic crust showing deceptively as a basement high. The effective 
(A)

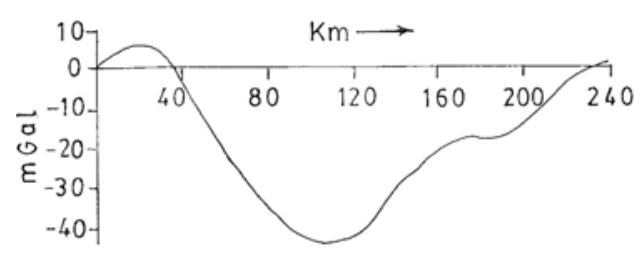

(B)

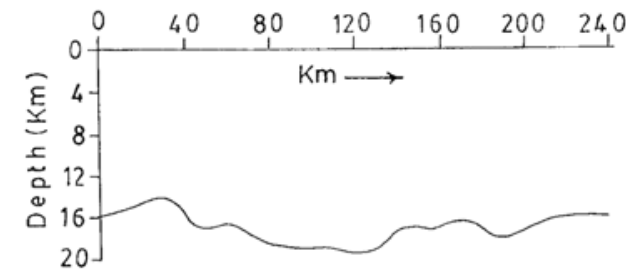

(c)

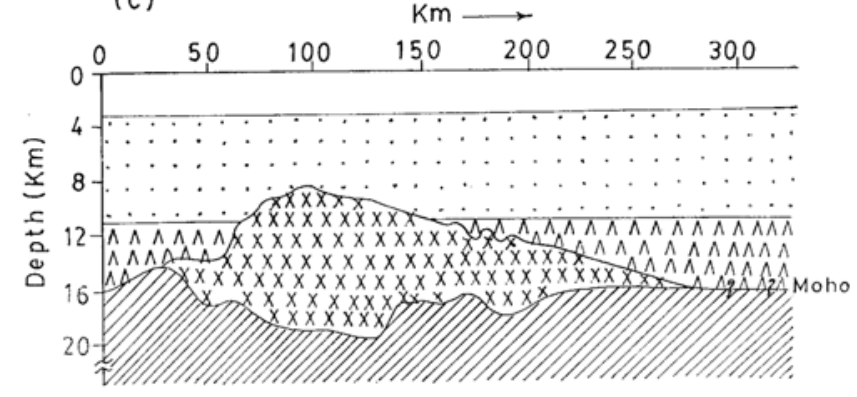

$\square$ Seawater $\square$ Sediments $\quad \triangle 1$ Oceanic crust/Basalts

Mantle $\times \bar{x}$ Volcanicmaterial

Figure 6. Gravity anomaly (A) over the anomalous feature in the $\mathrm{K}-\mathrm{G}$ basin and its inversion for structures in Moho (B). The probable geological cross-section section explaining the gravity and magnetic anomalies is shown in (C).

magnetizations of $0.015 \mathrm{cgs}$ units with a dip of $+30^{\circ}$ for $85^{\circ} \mathrm{E}$ Ridge and $0.007 \mathrm{cgs}$ units with a dip of $-25^{\circ}$ for the structure in the $\mathrm{K}-\mathrm{G}$ basin may indicate the possibility of exhumation of volcanic material at two different geological times with reverse and normal polarity.

The discussed NE-SW trend magnetic anomaly on the margin is away from another significant anomaly associated with the $85^{\circ} \mathrm{E}$ Ridge. On the basis of seismic results earlier Gopala Rao et al (1997) have correlated the margin structure with another structure that lies on the west of $85^{\circ} \mathrm{E}$ Ridge at $13^{\circ} \mathrm{N}$ latitude and suggested the presence of NW trending fracture zone. Subsequent new ship-borne geophysical and satellite geoid and gravity datasets (Krishna 2003; Krishna et al 2009) have brought more clarity on structural fabric within the western basin, particularly outlining of fracture zones and locations of structural highs. Interestingly the structural highs are orthogonal to the trends of fracture zones.

The ECMI had witnessed two continental breakups in the early stages of eastern Gondwana
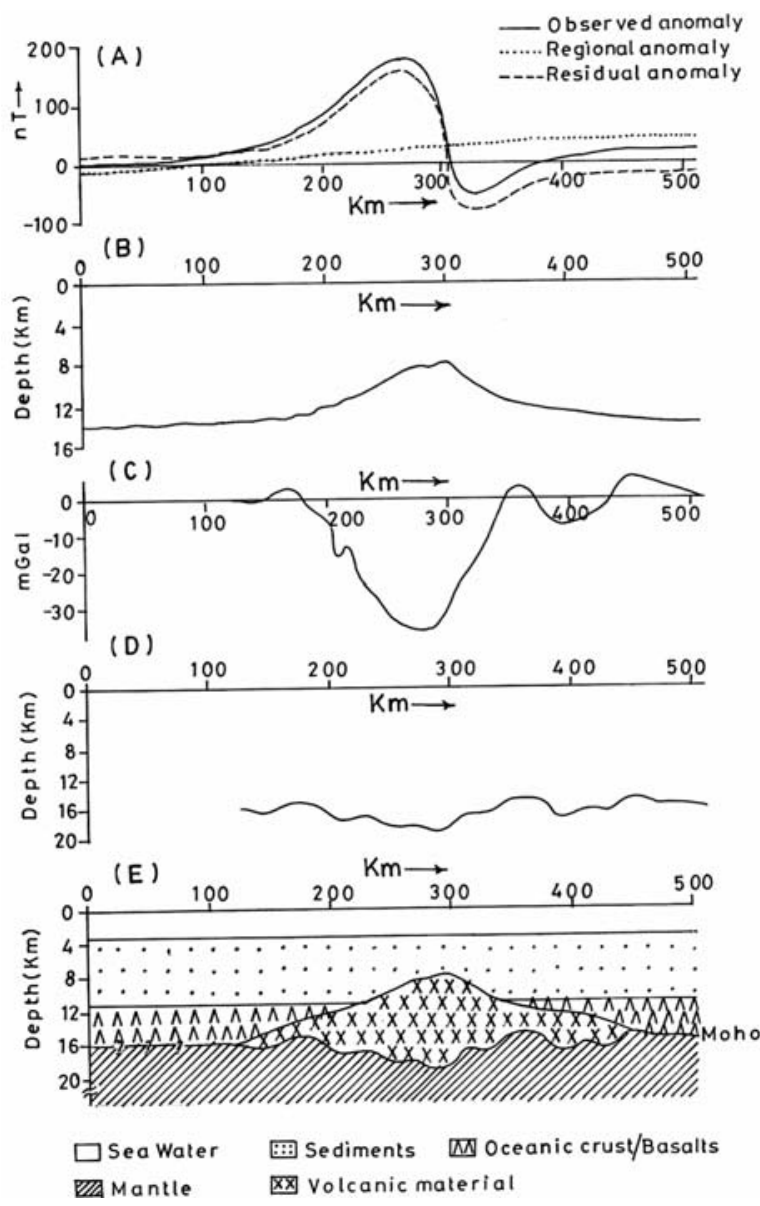

Figure 7. Inversion of total field magnetic (A) and free-air gravity (C) anomalies observed along MAN-01 profile over $85^{\circ} \mathrm{E}$ Ridge. Interpreted structures are shown in (B) and (D) respectively. The plausible geological cross-section below the ridge is shown in $(\mathbf{E})$.

splitting. The first break-up occurred with separation of Greater India from Australia and East Antarctica during the Early Cretaceous (Curray et al 1982; Royer and Coffin 1992; Gopala Rao et al 1997; Müller et al 2000). In the second stage, the Elan Bank, a micro-continent, which presently lies on the western margin of the Kerguelen Plateau in the southern Indian Ocean, got detached from the eastern margin of India at about $120 \mathrm{Ma}$ (Gaina et al 2003). From these results, it can be inferred that most part of the oceanic crust in the Bay of Bengal was evolved during the Cretaceous Magnetic quiet period (120-84 Ma). Hence there are no pronounced magnetic anomaly lineations observed in the Bay of Bengal as there is no contrast of magnetic polarity in the oceanic crust (Murthy et al 1993; Gopala Rao et al 1997; Subrahmanyam et al 1997). At subsequent ages during the late Cretaceous the Crozet hotspot had emplaced the $85^{\circ} \mathrm{E}$ Ridge and some isolated structural highs on already evolved Cretaceous quiet period oceanic crust. The $85^{\circ} \mathrm{E}$ Ridge has began its formation at 
$\sim 85 \mathrm{Ma}$ in northern Bay of Bengal and formed on older $(\sim 35$ m.y. $)$ oceanic crust of the Bay of Bengal. As the $85^{\circ} \mathrm{E}$ Ridge and the isolated structural high considered in the present study are younger than underlying oceanic crust, the lithosphere beneath the ridge and the structural high are down-flexed up to $4 \mathrm{~km}$ in response to the volcanic loads. From the different dips of effective magnetization for the volcanic rocks of the $85^{\circ} \mathrm{E}$ Ridge at $14.64^{\circ} \mathrm{N}$ latitude and structural high close to the margin predicted in this study, it may be inferred that they were formed in reversed and normal geomagnetic periods after Cretaceous magnetic quiet period.

\section{Acknowledgements}

$\mathrm{K} \mathrm{V} \mathrm{S}$ is thankful to the Indian Academy of Sciences, Bangalore for the award of Summer Research Fellowship to work at National Institute of Oceanography, Goa. I V R acknowledges the support of CSIR for Emeritus Scientist position. This is NIO contribution no. 4526.

\section{References}

Curray J R, Emmel F J, Moore D G and Russel W R 1982 Structure, tectonics, and geological history of the northeastern Indian Ocean, In: The Ocean Basins and Margins, The Indian Ocean (eds) Nairn A E and Stehli F G (New York: Plenum) 6 399-450.

Gaina C, Müller R D, Brown B and Ishihara T 2003 Microcontinental formation around Australia; In: The evolution and dynamics of the Australian Plate (eds) Hillis R and Muller R D, Joint Geol. Soc. of Aust. Am. Spec. Pap. 22 399-410.

Gopala Rao D, Krishna K S and Sar D 1997 Crustal evolution and sedimentation history of the Bay of Bengal since the Cretaceous; J. Geophys. Res. 102(B8) $17,747-17,768$.

Krishna K S 2003 Structure and evolution of the Afanasy Nikitin seamount, buried hills and $85^{\circ} \mathrm{E}$ Ridge in the northeastern Indian Ocean; Earth Planet. Sci. Lett. 209 379-394.

Krishna K S, Michael L, Bhattacharyya R and Majumdar T J 2009 Geoid and gravity anomaly data of conjugate regions of Bay of Bengal and Enderby Basin New constraints on breakup and early spreading history between India and Antarctica; J. Geophys. Res. 114 B03102, doi:10.1029/2008JB005808.

Kumar S P 1983 Geology and hydrocarbon prospects of Krishna-Godavari and Cauvery basins; Petroleum Asia Journal 6 57-65.

Liu C S, Sandwell D T and Curray J R 1982 The negative gravity field over the $85^{\circ} \mathrm{E}$ Ridge; J. Geophys. Res. 87 7673-7686.

Müller R D, Gaina C, Tikku A, Mihut D, Cande S and Stocvk J M 2000 Mesozoic/Cenozoic tectonic events around Australia; In: The history and dynamics of Global Plate Motions (eds) Richards M A, Gordon R G and Vander Hilst R D, pp. 161-189, AGU Geophysical Monograph 121.

Murthy K S R, Rao T C S, Subrahmanyam A S, Rao M M M and Lakshminarayana S 1993 Structural lineaments from the magnetic anomaly map of the eastern continental margin of India (ECMI) and NW Bengal Fan, Marine Geology 114 171-183.

Murthy K S R, Subrahmanyam A S, Lakshminarayana S, Chandrasekhar D V and Rao T C S 1995 Some geodynamic aspects of Krishna-Godavari Basin, east coast of India, Cont. Shelf Res. 15 779-788.

Radhakrishna Murthy I V 1998 Gravity and magnetic interpretation in exploration geophysics; Geological Society of India, Memoir 45, Bangalore.

Ramana M V, Subrahmanyam V, Chaubey A K, Ramprasad T, Sarma K V L N S, Krishna K S, Maria Desa, Murthy G P S and Subrahmanyam C 1997 Structure and origin of the $85^{\circ} \mathrm{E}$ Ridge, J. Geophys. Res. 102 17,995-18,012.

Royer J Y and Coffin M F 1992 Jurassic to Eocene plate tectonic reconstructions in the Kerguelene Plateau region; In: Proc. Ocean Drilling Prog. (eds) Wise J S W, Julson A P, Schlich R and Thomas E, Sci. Res. 120 917-930. Texas A \& M University, College Station, TX.

Sahni A 1982 The structure, sedimentation and evolution of Indian continental margins; In: The ocean basins and margins, Indian Ocean (eds) Nairn A E M and Stehli G G (New York: Plenum Press) 353-398.

Shastri V V, Sinha R N, Singh G and Murti K V S 1973 Stratigraphy and tectonics of sedimentary basins on the east coast of India; American Association of Petroleum Geologists Bulletin 57 655-678.

Shastri V V, Venkatachala B S and Narayanan V 1974 Evolution of Mesozoic sedimentary basins on the east coast of India; APEA J. 14 29-41.

Shenai K R and Rao M S 1982 Exploration in the offshore Godavari-Krishna basins; Bulletin of ONGC 19(2) 293-300.

Subrahmanyam A S, Murthy K S R, Lakshminarayana S, Rao M M M, Venkateswarlu K and Rao T C S 1997 Magnetic expression of some major lineaments and Cretaceous quiet zone in the Bay of Bengal; Geo-Marine Lett. $17202-206$

Subrahmanyam C, Thakur N K, Gangadhara Rao T, Ramesh Kanna, Ramana M V and Subrahmanyam V 1999 Tectonics of the Bay of Bengal: New insights from satellite-gravity and ship-borne geophysical data; Earth Planet. Sci. Lett. 171 237-251.

Subrahmanyam V, Krishna K S, Radhakrishna Murthy I V, Sarma K V L N S, Maria Desa, Ramana M V and Kamesh Raju K A 2001 Gravity anomalies and crustal structure of the Bay of Bengal; Earth Planet. Sci. Lett. 192 447-456.

Venkateswarlu P D, Raghava Rao A M V and Bose P K 1992a Marine magnetic anomalies and associated tectonics along the east coast of India; In: Recent geoscientific studies in the Bay of Bengal and the Andaman Sea; Geol. Surv. India Spec. Publ. 29 61-70.

Venkateswarlu P D, Sengupta B J, Raghava Rao A M V and Bose P K 1992b Marine magnetic indication of a possible submerged volcano off Machilipatnam in Bay of Bengal; J. Geological Soc. India 39 197-203. 